\title{
MIR152 Gene
}

National Cancer Institute

\section{Source}

National Cancer Institute. MIR152 Gene. NCI Thesaurus. Code C81780.

This gene is involved in the regulation of gene expression. While it has no known role in oncogenesis, MIR152 plays a role in the development of asthma. 